\title{
OVERCONFIDENCE AND INITIAL PUBLIC OFFERING (IPO) DECISIONS: A BEHAVIOURAL CORPORATE FINANCE SURVEY AMONG POLISH MANAGERS
}

Objective. The aim of this study was to examine whether corporate managers, i.e. chief executive officers (CEOs) and the chief financial officers (CFOs) of the companies listed on the Main Market of the Warsaw Stock Exchange (WSE) are susceptible to overconfidence bias and whether their overconfidence is related to their managerial practices in the process of going public (Initial Public Offering, IPO).

Methods. A survey methodology was employed to identify the existence of overconfidence bias and to investigate the IPO managerial practices among the study participants. Fully completed surveys were obtained from 163 corporate managers.

Results. The Polish corporate managers displayed overconfidence bias and also revealed several irrational managerial practices connected with IPO decisions. Importantly, the authors observed the connection between managerial overconfidence and some elements of the IPO practices among the study participants.

Conclusions. It appears that even well-educated corporate managers with a high level of expertise who represent publicly listed companies, are susceptible to overconfidence bias. This may be related to their irrational managerial practices in the area of IPO decisions. Further research on behavioural corporate finance is needed to better understand the psychological obstacles that face managers in their everyday decisions regarding a company's value creation. finance

Keywords: behavioural biases, overconfidence, corporate managers, behavioural corporate

DOI: $10.15611 /$ aoe.2020.1.10

\section{INTRODUCTION}

One of the most significant changes observed in economics at the end of the 20th century and the beginning of the 21st was the increasing role of behavioural economics and finance (Shiller, 2003; Camerer and Loewenstein, 2003; Kahneman, 2012). Behavioural finance is an important component of behavioural economics, relying heavily on psychology, it incorporates

\footnotetext{
*Faculty of Psychology, University of Warsaw.

** Department of Capital Markets, Collegium of World Economy, Warsaw School of Economics.
} 
selected psychological findings with the study of investor behaviour and research on the stock market on the aggregate level (e.g. Akerlof and Schiller, 2009; Thaler, 2005, 2015; van der Sar, 2004). Proving that humans have restrained cognitive possibilities and are controlled by emotions in the decision-making process, extensive literature on cognitive psychology has drawn attention of behavioural finance proponents to the drawbacks of the assumptions regarding the rationality of investors (e.g. homo oeconomicus) and their susceptibility to so-called behavioural biases, stemming from cognitive errors and heuristics (Baddeley, 2013; Kahneman and Tversky, 1979; Kahneman, 2012). These biases disrupt the rationality of the decisionmaking process among investors and contribute to inefficient stock market reactions to information, causing various anomalies of the capital markets, which cannot be explained by the neoclassical finance theory (De Bondt and Thaler, 1987; Thaler, 2015).

\section{LITERATURE REVIEW}

As mentioned above, behavioural finance has become increasingly popular in recent years. Some authors maintain that this relatively new school in finance may become a new paradigm in finance theory in the near future (De Bondt et al., 2008). Nevertheless, some areas in behavioural finance remain significantly understudied and require further investigation. One such field is behavioural corporate finance, which aims to explain corporate decisions in the world of inefficient capital markets and/or irrational managers. It shows how psychological phenomena (i.e. behavioural biases) are related to the bounded rationality of both managers and investors, which in turn obstructs the process of a company's value creation or causes market mispricing. The behavioural approach offers an alternative look at areas of corporate finance such as capital structure, investment activity, and project finance and earnings management. Among others, it explains numerous puzzles regarding initial public offerings (IPO) and mergers and acquisitions (M\&A), the continuation of unprofitable investment projects, earnings smoothing and catering for dividend policy (Baker and Wurgler, 2004, 2013; Szyszka, 2013). There are two main approaches in behavioural corporate finance. The first, 'rational managers-irrational investors', describes how rational corporate managers adjust their decisions to the manifestations of the irrationality of investors. It focuses on how a smart manager adapts corporate policy to take advantage of the investors' irrationality and market inefficiency. The second approach replaces the assumption of managers' rationality with various 
evidence-based psychological inclinations. Its purpose is to investigate how the irrational behaviour of corporate managers affects corporate policy and influences the value of a company. The authors based their study on the latter theoretical approach, seeking behavioural biases among corporate managers.

Until now, behavioural finance proponents have focused mainly on behavioural biases among stock market investors and their influence on the valuation of securities (e.g. De Bondt and Thaler, 1987; Shefrin and Statman, 1985; Baddeley, 2013; Thaler, 2005, 2015). Studies on the biases and heuristics among corporate managers remain relatively scarce (e.g. De Bondt and Thaler, 1994; Baker and Nofsinger, 2010; Szyszka, 2013). Howe-ver, managers are only human and despite being generally well educated in economics and finance, they may display bounded rationality and be susceptible to numerous behavioural biases (Szyszka, 2013). In this study, 'irrational managerial practices' are defined as behaviour that departs from the neoclassical corporate finance theory assumptions (Damodaran, 2001), for example, the maximisation of a shareholder's wealth under rational expectations and the neoclassical expected utility theory. Since the research was based entirely on a behavioural approach (Baker and Wurgler, 2004, 2013), the authors did not test other theories in corporate finance - such as moral hazard behaviour, the misalignment of managerial and shareholder interests ('agency theory') or the theory of information asymmetry (Welch, 2009) - which are related to the irrational behaviour of managers.

Instead, the study focused on 'overconfidence', one particular behavioural bias that is frequently displayed by managers, as captured by the generalised behavioural asset pricing model (Szyszka, 2008, 2010). Overconfidence bias has been documented in numerous samples and it typically manifests itself in four aspects: the above-average effect, calibration bias, illusion of control and excessive optimism (Langer, 1975; Lichtenstein et al., 1982; Weinstein, 1980). The aforementioned aspects of overconfidence have also been observed among corporate managers (e.g. Ben-David et al., 2007; Malmendier and Tate, 2005a, 2005b, 2008, 2015; Malmendier et al., 2011; Niu, 2010; Peon et al., 2016; Szyszka, 2013).

Extensive literature indicates that the decision to go public (IPO) is driven by market-timing attempts by corporate managers and is frequently motivated by temporary overvaluation (Lerner, 1994; Pagano et al., 1998; Loughran et al., 1994). There is also a corporate-timing hypothesis suggesting that managers pick the moment for the IPO after a period of superior performance of the company, so that the favourable historical results could be extrapolated into the future and possibly justify the high valuation. This 
hypothesis is supported by evidence of poor post-IPO performance, both in terms of operational results (Jain and Kini, 1994; Mikkelson, Partch, and Shah, 1997; Pagano et al., 1998) and negative abnormal long-term post-IPO stock returns (Ritter, 1991; Loughran and Ritter, 1995). Survey evidence strongly supports both market-timing and corporate-timing motivations. In interviews conducted by Graham and Harvey (2001) and Brau and Fawcett (2007), going-public managers directly admitted that the desire to capitalise on the firm's good historical results, overvaluation, and general market conditions were important choice determinants in their timing of the IPO.

However, all of the managerial practices related to the IPO described above fall within the first framework of behavioural corporate finance mentioned earlier ('rational managers-irrational investors'). The innovation of this paper is in its attempt to also link IPO decisions to irrational managerial behaviour as represented by overconfidence bias.

\section{CURRENT STUDY}

The first aim of this study was to examine whether corporate managers are susceptible to overconfidence bias (see the above-average effect, calibration bias, illusion of control and excessive optimism). This aim was accomplished by looking at the chief executive officers (CEOs) and the chief financial officers (CFOs) of the companies listed on the Main Market of the Warsaw Stock Exchange (WSE) and NewConnect (NC), the alternative market, which is also run by the WSE. The second aim was to test the existence of irrational managerial practices in the area of the decision to go public (IPO). Finally, the authors wanted to explore whether the above mentioned aspects of managerial overconfidence are related to the aforementioned selected aspects of their managerial practices devoted to IPO decisions. Due to relatively scarce and ambiguous literature on behavioural corporate finance, especially in the context of the third aim in this specific sample of participants, this study was mainly explorative in nature; therefore, no formal hypotheses were specified.

\section{METHOD}

\subsection{Participants and procedure}

A survey methodology was employed to identify the existence of overconfidence bias and irrational managerial practices among the study participants (see Appendix). The research questionnaire was adopted from Szyszka's 
(2013) studies on the behavioural aspects of corporate finance. Some basic numerical information about the characteristics of the company are included first; this includes such things as the number of members of the board, the role top management has in the board (CEO, CFO or other), the net income and the balance sheet total of the company in the last year (see Table 1). In the part of the questionnaire directed towards measuring overconfidence bias, the respondents had to decide how they would behave in hypothetical situations; they were provided with a number of options but could only choose one (see Tables 2-11). The susceptibility to overconfidence was assessed in each of the scenarios, which were all adapted from the behavioural economics literature (see Kahneman, 2012). In the second part of the questionnaire, which was aimed at measuring managerial practices in the area of IPO decisions, the participants were asked to reveal their practices devoted to selected determinants of their decisions regarding going public (see Tables 12-22).

The questionnaires were sent to the CEOs and the CFOs of the companies listed on both the main and the alternative market, NewConnect, run by the Warsaw Stock Exchange (the third most active market in Europe in 2017). An external company performed the survey between April and November 2018. The invitation was sent to 949 companies and was followed by e-mails and phone calls to increase the participation in the study. Companies from various sectors were included, such as construction, light engineering, heavy engineering, extraction industry, chemical industry, biotechnology and pharmacy, information technology and the retail trade. Due to their different characteristics and specific business approaches, the authors did not include companies from the financial sector. The questionnaires were sent to participants via computer assisted telephone interview (CATI) and computer-assisted web interview (CAWI), in electronic format with the aid of a specially designed webpage. The survey was designed with unique tokens with which it was possible to fully control the status of the implementation of the study and secure against the same respondent filling out the questionnaire more than once. Since revealing the true corporate practices in publicly listed companies is very sensitive, to encourage participants to give honest answers, the authors strongly emphasised the anonymity of the survey. They were additionally motivated to complete the entire survey by the promise that a fixed charity donation would be made for each completed questionnaire. In the last survey question, the respondents declared their preferred charity goal and were informed that the one with the largest number of votes would receive the entire sum of money, depending on the number of active participants. 
The authors managed to obtain fully completed surveys from 163 corporate managers, an approximate $17 \%$ response rate, which is comparable to other studies from this field (see Graham and Harvey, 2001). The characteristics of the companies in our study sample is presented in Table 1.

Table 1

Numerical characteristics of the companies

The number on the company's management board:

\begin{tabular}{l|c|c}
\hline Single person & 15 & $9.2 \%$ \\
\hline Multi-person, but financial decisions are made by the CFO & 47 & $28.8 \%$ \\
\hline Multi-person in which financial decisions are taken collegially & 101 & $62.0 \%$ \\
\hline
\end{tabular}

Held position:

\begin{tabular}{l|c|c}
\hline CEO & 31 & $19.0 \%$ \\
\hline CFO, Member of the Board & 46 & $28.2 \%$ \\
\hline CFO, but not a Member of the Board & 23 & $14.1 \%$ \\
\hline Other top managerial positions & 63 & $38.7 \%$ \\
\hline
\end{tabular}

The net revenues of the company in the last reporting year are in the range of:

\begin{tabular}{l|l|l}
\hline Below PLN 100 million & 52 & $31.9 \%$ \\
\hline PLN 100-500 million & 36 & $22.1 \%$ \\
\hline PLN 3.5 million-1 billion & 53 & $32.5 \%$ \\
\hline PLN 4-1 billion & 22 & $13.5 \%$ \\
\hline
\end{tabular}

The total assets of the company at the end of the last reporting year were:

\begin{tabular}{l|l|l}
\hline Below PLN 100 million & 53 & $32.5 \%$ \\
\hline PLN 100-500 million & 37 & $22.7 \%$ \\
\hline PLN 500 million-1 billion & 45 & $27.6 \%$ \\
\hline PLN over 1 billion & 28 & $17.2 \%$ \\
\hline
\end{tabular}

The share of debt in enterprise financing (i.e. interest liabilities to the balance sheet total at the end of the last reporting year) was about $7.96 \%(\mathrm{SD}=7.46)$

The company operates in the sector:

\begin{tabular}{l|c|c|l|c|c}
\hline Construction & 23 & $14.1 \%$ & Chemical & 7 & $4.3 \%$ \\
\hline Light industry & 6 & $3.7 \%$ & Heavy industry & 1 & $.6 \%$ \\
\hline Mining industry & 3 & $1.8 \%$ & Trade & 29 & $17.8 \%$ \\
\hline Biotechnology and pharmacy & 17 & $10.4 \%$ & IT & 27 & $16.6 \%$ \\
\hline Other & 50 & $30.7 \%$ & \\
\hline
\end{tabular}

State Treasury held over $15 \%$ of the company's shares

\begin{tabular}{|c|c|c|c|c|c|}
\hline Yes & 18 & $11.0 \%$ & No & 145 & $89.0 \%$ \\
\hline \multicolumn{6}{|c|}{ The company's shares are listed on: } \\
\hline Main Market & 108 & $66.3 \%$ & NewConnect & 55 & $33.7 \%$ \\
\hline
\end{tabular}

Source: authors' own. 


\section{DATA ANALYSIS}

The statistical analysis was designed and conducted to either confirm or deny the presence of a bias for overconfidence and managerial practices; for IPO practices, the authors wanted to identify the managerial motivations among corporate managers. Finally, it was ascertained whether there was any statistically significant relationship between their overconfidence and the declared IPO motivation. The frequency distributions of the answers to each question concerning overconfidence and managerial practices were analysed using a one-sample chi-squared test. If the result was statistically significant, it meant that the chosen answers were not evenly distributed. The relations between the studied variables were analysed using a likelihood relation, which is analogous to Pearson's chi-squared test of independence, but it does not require the assumption of the expected frequency being 5 or less in the case of independence to be met. If the result was statistically significant, it meant that the analysed variables were related to each other. To test whether there were dependencies between the overconfidence and the IPO decisions, the distributions of the variables from the area of overconfidence for particular levels of variables from the area of overconfidence were determined. The differences between these distributions were analysed. All of the calculations were conducted using the IBM SPSS 24 statistical package (SPSS Inc., 2016).

\section{RESULTS}

\subsection{Overconfidence among managers}

The frequency distributions of the participants' convictions about themselves are presented in Table 2.

The survey questions were designed so that there would be more or less the same number of answers identifying the respondents as above and below average for a given population in each of the groups $\left(\mathrm{H}_{0}: p=50 \%\right)$. If the percentage of people convinced of their above-average capabilities significantly exceeds $50 \%$, it shows that at least part of the respondents are overconfident in overestimating their skills in comparison with others $\left(\mathrm{H}_{1}: p>50 \%\right)$. In comparison, if the 'below-the-average' answers prevail significantly, it means that at least some of the respondents were insufficiently confident and underestimated their capabilities $\left(\mathrm{H}_{2}: p<50 \%\right)$. The results show that the decision-makers were convinced that they knew more about the economy 
than their average peers, $\chi^{2}(1)=17.12, p<0.001$, have less understanding of culture than the average person in their environment, $\chi^{2}(1)=11.34, p<0.01$, are less perceptive watching movies than the average viewer, $\chi^{2}(1)=18.56$, $p<0.01$ and that they do not have more luck in games of chance than the average Polish person in Poland, $\chi^{2}(1)=128.99, p<0.001$. Specifically, even if they were asked to compare themselves to their peers from the same profession, managers displayed overconfidence only in the area in which they were professionally active and felt more competent. This is in line with earlier studies by Lichtenstein and Fischhoff (1977), who suggested that experts are much more likely than the average person to fall into the trap of overconfidence in the area of their expertise.

Table 2

Participants' convictions about themselves

\begin{tabular}{l|r|c}
\hline $\begin{array}{l}\text { I know more about the economy than the average person in my } \\
\text { environment. }\end{array}$ & $n$ & $\%$ \\
\hline No & 55 & 33.7 \\
\hline Yes & 108 & 66.3 \\
\hline I have more insight in politics than the average person in my environment. & & \\
\hline No & 72 & 44.2 \\
\hline Yes & 91 & 55.8 \\
\hline $\begin{array}{l}\text { I have a greater understanding of culture than the average person in my } \\
\text { environment. }\end{array}$ & & \\
\hline No & 103 & 63.2 \\
\hline Yes & 60 & 36.8 \\
\hline I am more perceptive watching movies than the average viewer. & & \\
\hline No & 109 & 66.9 \\
\hline Yes & 54 & 33.1 \\
\hline I have a better sense of humour than the average person in Poland. & & \\
\hline No & 92 & 56.4 \\
\hline Yes & 71 & 43.6 \\
\hline I have more luck in games of chance than the average person in Poland. & & \\
\hline No & 154 & 94.5 \\
\hline Yes & 9 & 5.5 \\
\hline
\end{tabular}

Source: authors' own.

The frequency distributions of the participants' attitudes towards the change in the Warsaw Stock Exchange Index (WIG Index) during the next 12 months are presented in Table 3. 
Table 3

Participants' attitudes towards the change in the WIG Index during the next 12 months

\begin{tabular}{l|c|c}
\hline WIG Index for 12 months in relation to the present: & $N$ & $\%$ \\
\hline Will increase & 117 & 71.8 \\
\hline Will fall & 46 & 28.2 \\
\hline Total & 163 & 100.0 \\
\hline
\end{tabular}

Source: authors' own.

The decision makers predominantly displayed optimism considering the WIG Index change, $\chi^{2}(1)=30.93, p<0.001$.

The frequency distributions of the participants' expectations towards the increase in the WIG Index during the next 12 months are presented in Table 4.

Table 4

Participants' expectations towards the increase in the WIG Index during the next 12 months

\begin{tabular}{l|c|c}
\hline $\begin{array}{l}\text { WIG Index for } 12 \text { months in relation to the present will } \\
\text { increase: }\end{array}$ & $N$ & $\%$ \\
\hline Up to 5\% & 54 & 46.2 \\
\hline $6-10 \%$ & 34 & 29.1 \\
\hline $11-15 \%$ & 9 & 7.7 \\
\hline $16-20 \%$ & 10 & 8.5 \\
\hline $21-30 \%$ & 4 & 3.4 \\
\hline More than $30 \%$ & 6 & 5.1 \\
\hline Total & 117 & 100.0 \\
\hline
\end{tabular}

Source: authors' own.

Most of the respondents in the group of optimistic decision-makers expected that the WIG Index would increase by approximately $5 \%, \chi^{2}(5)=$ $103.77, p<0.001$.

The frequency distributions of the participants' expectations towards the fall in the WIG Index during the next 12 months are presented in Table 5.

Most of the decision-makers in the much smaller group of pessimists expected that the WIG Index would fall by up to $10 \%, \chi^{2}(4)=27.81$, $p<0.001$. 
Table 5

Participants' expectations towards the fall of the WIG Index during the next 12 months

\begin{tabular}{l|c|c}
\hline $\begin{array}{l}\text { WIG Index for } 12 \text { months in relation to the present will } \\
\text { fall: }\end{array}$ & $n$ & $\%$ \\
\hline Up to 5\% & 16 & 37.2 \\
\hline $6-10 \%$ & 18 & 41.9 \\
\hline $11-15 \%$ & 4 & 9.3 \\
\hline $16-20 \%$ & 3 & 7.0 \\
\hline More than 20\% & 2 & 4.7 \\
\hline Total & 43 & 100.0 \\
\hline
\end{tabular}

Source: authors' own.

The frequency distributions of the participants' estimated likelihood of meeting expectations considering the change in the WIG Index are presented in Table 6.

Table 6

Participants' expectations estimated likelihood of meeting expectations considering the change in the WIG Index

\begin{tabular}{l|c|c}
\hline $\begin{array}{l}\text { I estimate the likelihood of meeting my expectations } \\
\text { as predictable: }\end{array}$ & $n$ & $\%$ \\
\hline Up to $10 \%$ & 31 & 19.0 \\
\hline $11-20 \%$ & 13 & 8.0 \\
\hline $21-30 \%$ & 13 & 8.0 \\
\hline $31-50 \%$ & 55 & 33.7 \\
\hline $51-75 \%$ & 34 & 20.9 \\
\hline More than $75 \%$ & 17 & 10.4 \\
\hline Total & 163 & 100.0 \\
\hline
\end{tabular}

Source: authors' own.

The most prevalent estimate was $31-50 \%, \chi^{2}(5)=49.36, p<0.001$.

The frequency distributions of the participants' attitudes towards the change in the share price of their company during the next 12 months are presented in Table 7.

The decision-makers displayed unrealistic optimism in considering the change in the share price of their company, $\chi^{2}(1)=16.00, p<.001$.

The frequency distributions of the participants' expectations towards the increase in the share price during the next 12 months are presented in Table 8. 
Table 7

Participants' attitudes towards the change of the share price of their company during the next 12 months

\begin{tabular}{l|c|c}
\hline The share price for 12 months in relation to the present: & $n$ & $\%$ \\
\hline Will increase & 116 & 71.2 \\
\hline Will fall & 47 & 28.8 \\
\hline Total & 163 & 100.0 \\
\hline
\end{tabular}

Source: authors' own.

Table 8

Participants' expectations towards the increase of the share price during the next 12 months

\begin{tabular}{l|c|c}
\hline $\begin{array}{l}\text { The share price in } 12 \text { months in relation to the present will } \\
\text { increase: }\end{array}$ & $n$ & $\%$ \\
\hline Up to 5\% & 33 & 28.4 \\
\hline $6-10 \%$ & 27 & 23.3 \\
\hline $11-15 \%$ & 13 & 11.2 \\
\hline $16-20 \%$ & 13 & 11.2 \\
\hline $21-30 \%$ & 15 & 12.9 \\
\hline More than 30\% & 15 & 12.9 \\
\hline Total & 116 & 100.0 \\
\hline
\end{tabular}

Source: authors' own.

Most of the decision-makers expected that the share price of their company would increase by up to $10 \%, \chi^{2}(5)=18.79, p<0.001$. It is interesting that the results from Tables 7 and 8 indicate that the degree of optimism among corporate managers regarding the share price of their own company was greater than the degree of optimism regarding the general market situation represented by the level of the WIG Index.

Table 9

Participants' expectations towards the fall of the share price during the next 12 months

\begin{tabular}{l|c|c}
\hline The share price in 12 months in relation to the present will fall: & $n$ & $\%$ \\
\hline Up to 5\% & 16 & 38.1 \\
\hline $6-10 \%$ & 10 & 23.8 \\
\hline $11-15 \%$ & 3 & 7.1 \\
\hline $16-20 \%$ & 8 & 19.0 \\
\hline More than $20 \%$ & 5 & 11.9 \\
\hline Total & 42 & 100.0 \\
\hline
\end{tabular}

Source: authors' own. 
The frequency distributions of the participants' expectations towards the fall of the share price during the next 12 months are shown in Table 9.

Most of the decision-makers in the group of pessimists expected that the share price would fall by up to $10 \%, \chi^{2}(4)=12.05, p<0.05$, similarly to the expectations of the general market situation (Table 5).

The frequency distributions for the participants' predictions about the share price of a company whose prospects are assessed positively after a thorough analysis in the following week are presented in Table 10.

Table 10

Participants' predictions about the share price of a company whose prospects are assessed positively after a thorough analysis

\begin{tabular}{l|c|c}
\hline $\begin{array}{l}\text { Participants' predictions about the share price of a company whose } \\
\text { prospects are assessed positively: }\end{array}$ & $n$ & $\%$ \\
\hline The share price will increase & 54 & 33.1 \\
\hline The share price will go down & 16 & 9.8 \\
\hline It is impossible to predict & 93 & 57.1 \\
\hline Total & 163 & 100.0 \\
\hline
\end{tabular}

Source: authors' own.

Most of the decision-makers had the opinion that the share price was impossible to predict, $\chi^{2}(2)=54.56, p<0.001$. However, nearly $43 \%$ of the respondents displayed some form of overconfidence declaring that because of their own thorough analysis, they were able to predict future share prices.

The frequency distributions for the participants' predictions regarding the share price of a company whose prospects were assessed negatively are presented in Table 11.

Table 11

Participants' predictions about the share price of a company whose prospects are assessed negatively

\begin{tabular}{l|c|c}
\hline $\begin{array}{l}\text { Participants' predictions about the share price of a company whose } \\
\text { prospects are assessed negatively: }\end{array}$ & $n$ & $\%$ \\
\hline The share price will increase. & 20 & 12.3 \\
\hline The share price will go down. & 57 & 35.0 \\
\hline It is impossible to predict. & 86 & 52.8 \\
\hline Total & 163 & 100.0 \\
\hline
\end{tabular}

Source: authors' own. 
Again, most decision-makers had the opinion that the share price was impossible to predict, $\chi^{2}(2)=40.28, p<0.001$. However, when it came to the companies with a pessimistic outlook, nearly half of the respondents displayed overconfidence bias in declaring superior analytical skills that allowed them to predict future share prices.

\subsection{IPO decisions among managers}

The frequency distributions of the motives concerning the public issue of shares and entry on the WSE are presented in Table 12.

Table 12

Decisions concerning the IPO

\begin{tabular}{l|c|c}
\hline $\begin{array}{l}\text { The decision to go public on the Warsaw Stock Exchange } \\
\text { was dictated by: }\end{array}$ & $n$ & $\%$ \\
\hline The capital needs of the company & 95 & 58.3 \\
\hline $\begin{array}{l}\text { The need to sell some or all of the shares by existing } \\
\text { shareholders }\end{array}$ & 24 & 14.7 \\
\hline A booming stock market and possible valuation of shares & 17 & 10.4 \\
\hline $\begin{array}{l}\text { The desire to capitalise on the company's good historical } \\
\text { results }\end{array}$ & 8 & 4.9 \\
\hline The desire to strengthen the company's marketing position & 19 & 11.7 \\
\hline Total & 163 & 100.0 \\
\hline
\end{tabular}

Source: authors' own.

Most of the managers declared that the decision to go public was based on the capital needs of the company, $\chi^{2}(4)=153.41, p<0.001$.

The frequency distributions of the opinions considering the current share price of their company are presented in Table 13.

Table 13

Opinions considering the current share pricing of the company.

\begin{tabular}{l|c|c}
\hline The shares of the company are currently: & $n$ & $\%$ \\
\hline Properly valued by the market & 53 & 32.5 \\
\hline Undervalued & 106 & 65.0 \\
\hline Overvalued & 4 & 2.5 \\
\hline Total & 163 & 100.0 \\
\hline
\end{tabular}

Source: authors' own. 
Most decision-makers $(65 \%)$ were of the opinion that their shares were undervalued, $\chi^{2}(2)=95.97, p<0.001$. They displayed overconfidence in the form of excessive optimism related to the firm they managed. Only four managers $(2.5 \%)$ admitted that their shares might be overvalued.

The frequency distributions of the IPO timing practices applied during the period of a long-term market boom are presented in Table 14.

Table 14

IPO timing during the period of a long-term market boom

\begin{tabular}{l|c|c}
\hline When preparing the IPO during the period of a long-term market boom: & $N$ & $\%$ \\
\hline $\begin{array}{l}\text { I am striving to make the IPO as fast as possible so that the prosperity } \\
\text { does not end. }\end{array}$ & 135 & 82.8 \\
\hline $\begin{array}{l}\text { I delay the date of the IPO to achieve the highest possible price for shares } \\
\text { in the public offer. }\end{array}$ & 28 & 17.2 \\
\hline Total & 163 & 100.0 \\
\hline
\end{tabular}

Source: authors' own.

Most of the decision-makers strived to conduct the IPO as fast as possible so that the prosperity did not end, $\chi^{2}(1)=70.24, p<0.001$.

The frequency distributions of the IPO timing practices that were applied during the long-term bear market are presented in Table 15.

Table 15

IPO timing during the long-term bear market

\begin{tabular}{l|c|c}
\hline When preparing the IPO during the long-term bear market: & $N$ & $\%$ \\
\hline $\begin{array}{l}\text { I am striving to make the IPO as fast as possible so that the market } \\
\text { situation will not deteriorate even more. }\end{array}$ & 54 & 33.1 \\
\hline $\begin{array}{l}\text { I delay the date of the IPO, hoping that the market situation will be reversed } \\
\text { soon and we will be able to obtain a higher price in the public offer. }\end{array}$ & 109 & 66.9 \\
\hline Total & 163 & 100.0 \\
\hline
\end{tabular}

Source: authors' own.

Most of the decision-makers delayed the moment of the IPO, hoping that the market situation would be reversed soon and that they would be able to obtain a higher price for shares in the public offer, $\chi^{2}(1)=18.56, p<0.001$. The results from Tables 14 and 15 indicate managerial overconfidence in the form of the belief of market timing ability, and they also confirm the disposition effect among corporate managers. Additionally, the results from 
Table 15 might be interpreted as a demonstration of ungrounded optimism among corporate managers regarding future reversals of the market.

The frequency distributions of the IPO pricing practices during the period of a long-term market boom are presented in Table 16.

Table 16

IPO pricing during the period of a long-term market boom

\begin{tabular}{l|c|c}
\hline When preparing the IPO during a long-term boom period: & $n$ & $\%$ \\
\hline $\begin{array}{l}\text { I am willing to offer investors a higher discount in the public offering in } \\
\text { relation to the market valuation, as the current market valuation of the } \\
\text { company is still very high. }\end{array}$ & 39 & 23.9 \\
\hline $\begin{array}{l}\text { I offer investors a lower discount in the public offer in relation } \\
\text { to the market valuation, because shares will find buyers easily during the } \\
\text { bull market. }\end{array}$ & 124 & 76.1 \\
\hline Total & 163 & 100.0 \\
\hline
\end{tabular}

Source: authors' own.

Since the bull market shares will find buyers easily, most of the participants would like to offer investors a lower discount in the public offer in relation to the market valuation, $\chi^{2}(1)=44.33, p<0.001$.

The frequency distributions of the IPO pricing practices applied during the long-term bear market are presented in Table 17.

Table 17

IPO pricing during the long-term bear market

\begin{tabular}{l|c|c}
\hline When preparing the IPO during the long-term bear market: & $n$ & $\%$ \\
\hline $\begin{array}{l}\text { I am willing to offer investors a lower discount in the public offer, as the } \\
\text { current market valuation of the company is low during the bear market. }\end{array}$ & 79 & 48.5 \\
\hline $\begin{array}{l}\text { I am willing to offer investors a higher discount in the public offering, to } \\
\text { make it easier to place shares in the unfavourable market situation. }\end{array}$ & 84 & 51.5 \\
\hline Total & 163 & 100.0 \\
\hline
\end{tabular}

Source: authors' own.

The two possible options were evenly distributed, $\chi^{2}(1)=0.15, p>0.05$. There is no statistical difference between the number of respondents ready to offer a higher or a lower IPO discount in a bear market. 


\subsection{The relationship between overconfidence bias and IPO decisions}

According to the value of likelihood ratio, the relation between decisions concerning to go public during the long-term bear market and the conviction of having more luck in games of chance than the average Pole was statistically significant, $\lambda(1)=4.48, p<0.05$. This conviction was present in six participants $(11.1 \%)$ who were striving to make the IPO as fast as possible and three $(2.8 \%)$ who were delaying the date of the IPO. In both situations, there was a similarity in the belief regarding the market timing ability and the belief that one has more luck in random games.

The frequency distributions for the length of the waiting period for the situation to improve depending on the IPO pricing decisions during the longterm boom are presented in Table 18.

Table 18

The length of the waiting period for the situation to improve depending on the decisions concerning the IPO pricing during the long-term boom

\begin{tabular}{l|c|c|c|c}
\cline { 2 - 5 } & \multicolumn{4}{c}{ IPO pricing } \\
\cline { 2 - 5 } & \multicolumn{2}{c}{ Higher discount } & \multicolumn{2}{c}{ Lower discount } \\
\hline \multicolumn{1}{c}{ Waiting period } & $N$ & $\%$ & $N$ & $\%$ \\
\hline Week & 4 & 10.3 & 2 & 1.6 \\
\hline Months & 1 & 2.6 & 7 & 5.6 \\
\hline Quarter & 5 & 12.8 & 10 & 8.1 \\
\hline Months & 14 & 35.9 & 56 & 45.2 \\
\hline Years & $\mathbf{1 5}$ & $\mathbf{3 8 . 5}$ & $\mathbf{3 1}$ & $\mathbf{2 5 . 0}$ \\
\hline To the effect & 0 & 0 & 18 & 14.5 \\
\hline
\end{tabular}

Note: $n$-number of participants; \% - percentage of the group.

Source: authors' own.

The relations between the variables were statistically significant, $\lambda(5)=$ $18.47, p<0.01$. If the market situation was unfavourable, the participants who offered a higher discount in the public offering during the long-term market boom more frequently wanted to wait, even for several years, for the situation to improve. This observation shows strong managerial overconfidence about market timing ability and it confirms the disposition effect.

The frequency distributions for the participants' predictions regarding the share price of a company whose prospects are assessed negatively after a thorough analysis depending on the IPO pricing decisions during the longterm boom are presented in Table 19. 
Table 19

Participants' predictions about the share price of a company whose prospects are assessed negatively after a thorough analysis depending on the IPO pricing decisions in the long-term boom

\begin{tabular}{l|c|c|c|c}
\cline { 2 - 5 } & \multicolumn{4}{c}{ IPO pricing } \\
\cline { 2 - 5 } & \multicolumn{2}{c}{ Higher discount } & \multicolumn{2}{c}{ Lower discount } \\
\hline \multicolumn{1}{c}{ Participants' predictions } & $n$ & $\%$ & $n$ & $\%$ \\
\hline The share price will increase. & 9 & 23.1 & 11 & 8.9 \\
\hline The share price will go down. & 15 & 38.5 & 42 & 33.9 \\
\hline It is impossible to predict. & $\mathbf{1 5}$ & $\mathbf{3 8 . 5}$ & $\mathbf{7 1}$ & $\mathbf{5 7 . 3}$ \\
\hline Total & & & & \\
\hline
\end{tabular}

Source: authors' own.

The relations between the variables were statistically significant, $\lambda(2)=$ 6.54, $p<0.05$. Participants who offered a lower IPO discount more frequently had the opinion that the share price was impossible to predict. Specifically, managers who declared to leave less 'money on the table' in the IPO process, more often displayed no overconfidence bias in attempts to predict future share prices.

The frequency distributions for the length of the waiting period for the situation to improve depending on the IPO pricing during the long-term market boom are presented in Table 20.

Table 20

The length of the waiting period for the situation to improve depending on the IPO pricing decisions during the long-term market boom

\begin{tabular}{l|c|c|c|c}
\cline { 2 - 5 } & \multicolumn{4}{c}{ IPO pricing } \\
\cline { 2 - 5 } \multicolumn{1}{c}{ Waiting period } & $n$ & $\%$ & $n$ & Lower discount \\
\hline Week & 6 & 7.6 & 0 & .0 \\
\hline Months & 3 & 3.8 & 5 & 6.0 \\
\hline Quarter & 4 & 5.1 & 11 & 13.1 \\
\hline Months & $\mathbf{3 9}$ & $\mathbf{4 9 . 4}$ & $\mathbf{3 1}$ & $\mathbf{3 6 . 9}$ \\
\hline Years & 20 & 25.3 & 26 & 31.0 \\
\hline To the effect & 7 & 8.9 & 11 & 13.1 \\
\hline
\end{tabular}

Source: authors' own.

The relation was statistically significant, $\lambda(5)=14.66, p<0.05$. The participants who offered a higher IPO discount in a booming market more frequently wanted to wait for months for the situation to improve if the 
market situation was unfavourable. In this case, the managers who declared to leave more 'money on the table' in the IPO process, more often displayed overconfidence bias in the form of ungrounded optimism when faced with bad market conditions. Again, this observation is also a confirmation of the disposition effect among corporate managers.

\subsection{Overconfidence and IPO decisions depending on the characteristics of the company}

The last part of the analysis was devoted to ascertaining whether the susceptibility of the managers to overconfidence bias and displaying irrational managerial practices may be related to the characteristics of their companies. The frequency distributions of the IPO motives in the companies listed on the Main Market of the Warsaw Stock Exchange and in the companies listed on the alternative market, NewConnect, are presented in Table 21.

Table 21

The IPO motives in the group of companies listed on the Main Market and in the group of companies listed on NewConnect

\begin{tabular}{l|c|c|c|c}
\cline { 2 - 5 } & \multicolumn{2}{c|}{ Main Market } & \multicolumn{2}{c}{ NewConnect } \\
\hline The decision on go public on the WSE was motivated by: & $n$ & $\%$ & $n$ & $\%$ \\
\hline The capital needs of the company & $\mathbf{6 7}$ & $\mathbf{6 2 . 0}$ & 28 & 50.9 \\
\hline $\begin{array}{l}\text { The need to sell some or all of the shares by existing } \\
\text { shareholders }\end{array}$ & $\mathbf{2 2}$ & $\mathbf{2 0 . 4}$ & 2 & 3.6 \\
\hline A booming stock market and possible valuation of shares & 8 & 7.4 & $\mathbf{9}$ & $\mathbf{1 6 . 4}$ \\
\hline $\begin{array}{l}\text { The desire to capitalise on the company's good historical } \\
\text { results }\end{array}$ & 5 & 4.6 & 3 & 5.5 \\
\hline The desire to strengthen the company's marketing position & 6 & 5.6 & $\mathbf{1 3}$ & $\mathbf{2 3 . 6}$ \\
\hline Total & 108 & 100.0 & 55 & 100.0 \\
\hline
\end{tabular}

Note: $n$ - number of respondents; $\%$ - percent of the group.

Source: authors' own.

The relation was statistically significant, $\lambda(4)=21.65, p<0.001$. The participants who worked in companies listed on the Main Market more frequently stated that the IPO decision was dictated by the capital needs of the company or the need to sell some or all of the shares by existing shareholders. The participants who worked in companies listed on NewConnect more frequently stated that the decision on the public issue of shares and 
entry on the WSE was motivated by a booming stock market and possible valuation of shares or by the desire to strengthen the company marketing position. These differences in IPO motives between the companies listed on the Main Market and those from NewConnect logically results from the different nature of these two markets. The Main Market is dedicated to bigger and more mature firms, and is far more liquid and has a significantly larger average IPO size. Therefore, it may be a platform for raising new capital or selling the shares of existing shareholders. In comparison, NewConnect is dedicated to small, fast-growing and frequently very innovative firms. NewConnect IPOs are typically of a relatively small size and the market is not very liquid. In these circumstances, an attractive market valuation and the recognition and marketing effect are far more important IPO motives than the possibility to raise new capital or sell the existing shares.

The frequency distributions of the opinions considering the shares of the company depending on the net revenues of the company in the last reporting year are presented in Table 22.

Table 22

Opinions considering the shares of the company depending on the net revenues of the company in the last reporting year

\begin{tabular}{l|c|c|c|c|c|c|c|c}
\cline { 2 - 10 } & \multicolumn{6}{c}{ The net revenues of the company in the last reporting year } \\
\cline { 2 - 10 } & \multicolumn{2}{c}{$\begin{array}{c}\text { PLN } \\
\text { below 100 million }\end{array}$} & \multicolumn{2}{c}{$\begin{array}{c}\text { PLN } \\
100-500 \text { million }\end{array}$} & $\begin{array}{c}\text { PLN } \\
\text { million-1 billion }\end{array}$ & \multicolumn{2}{c}{$\begin{array}{c}\text { PLN } \\
\text { over 1 billion }\end{array}$} \\
\hline $\begin{array}{l}\text { The shares of the } \\
\text { company are currently: }\end{array}$ & $n$ & $\%$ & $N$ & $\%$ & $n$ & $\%$ & $N$ & $\%$ \\
\hline Properly valued & 19 & 36.5 & 10 & 27.8 & 14 & 26.4 & $\mathbf{1 0}$ & $\mathbf{4 5 . 5}$ \\
\hline Undervalued & 29 & 55.8 & 26 & 72.2 & 39 & 73.6 & 12 & 54.5 \\
\hline Overvalued & 4 & 7.7 & 0 & .0 & 0 & .0 & 0 & .0 \\
\hline Total & 52 & 100 & 36 & 100 & 53 & 100 & 22 & 100 \\
\hline
\end{tabular}

Source: authors' own.

The relation between the two variables was statistically significant, $\lambda(6)=$ $13.27, p<0.05$. The participants working in the companies with the highest net revenues more frequently stated that the shares of the company were currently properly valued. This observation may be connected to the common belief that the market for large firms is typically more efficient while mispricing is more likely to occur in the segment of small-size companies. However, it is also possible that the managers of large firms 
have better capabilities while, the managers of smaller firms are more susceptible to psychological biases, including overconfidence and excessive optimism.

\section{DISCUSSION}

The results of our study show that corporate managers are susceptible to overconfidence bias. This finding is in line with other studies, which although still scarce, point to the bounded rationality of corporate managers and their tendency to overconfident behaviour (Baker and Wurgler, 2013; Szyszka, 2013). The tendency to display behavioural biases, and overconfidence in particular, may be a universal pattern in decision making, independent from professional specialisation or the level of expertise (Kahneman, 2012). More specifically, several authors proved that expertise or professional experience in a particular domain sometimes helps in making optimal decisions, however experts who are aware of their knowledge within a given domain can frequently fall prey to various behavioural biases, sometimes to a greater degree than ordinary people (Itzkowitz and Itzkowitz, 2017; Krems and Zierer, 1994; Rzeszutek et. al, 2015; Stephan and Kiell, 2006). This is especially true in the corporate world, which is full of complex and idiosyncratic decisions with a large number of information signals providing potential settings for susceptibility to behavioural biases (Nguyen and Schussler, 2013).

In considering the above factors, it is not surprising that our participants also revealed several irrational managerial practices connected to IPO decisions. Namely, although the most important reason to go public was the need for capital, which is in accordance with the neoclassical finance theory (Damodaran, 2001), it is imperative to note that almost half of our participants choose irrational options, such as a favourable stock market situation, the desire to capitalise on the company's good historical financial results or strengthening PR and marketing effects. More specifically, the authors observed that the IPO decision was related to the market-timing or companyspecific conditions, such as the willingness to achieve a high valuation due to positive general market conditions or a company's historically good performance, which could have been extrapolated by investors into a favourable future. This is in line with other studies (Graham and Harvey, 2001; Szyszka, 2013). 
The final aim was the most innovative part of our study; it was to explore whether overconfidence bias among the corporate managers was related to the IPO decisions. It occurred to the authors that overconfidence (the aboveaverage effect, illusion of control and unrealistic optimism) might be linked to irrational practices in IPO. Market-timing and corporate-timing practices are typically treated as attempts of rational managers to exploit market inefficiencies and investors' biases. This paper suggests that at least to some extent these practices might result also from managerial biases, i.e. overconfidence. Overconfident managers overestimate their market-timing skills and ability to predict the future market situation. Overconfidence is also closely linked to excessive optimism. Besides overconfidence, the authors also identified managerial behaviour that fits the disposition effect pattern.

In attempting to interpret these results, one should bear in mind that, until now, no such research linking directly via statistical analyses, psychological biases and the studied financial decisions among corporate managers has been conducted. Therefore, this part of the study is mainly explorative. Nevertheless, the authors may refer to some studies exploring the connection between behavioural biases and the general irrational behaviour of managers. In fact, managerial overconfidence was observed to be related to the underestimation of risk and erroneous predictions regarding a company's future prospects (Ben-David et al., 2007; Malmendier et al., 2011). Specifically, when faced with a decision about financing a new investment project, an overconfident manager underestimates the risk of failure, while his/her excessive optimism is responsible for overestimating the potential gain that the investment may bring (Brown et al., 2006). Furthermore, managerial overconfidence and excessive optimism are associated with a standard pecking-order preference, such as the preference of internal financing to risky debt and risky debt-to-equity ratio (Ljungqvist and Wilhelm 2005). Overconfidence among managers may also explain why an IPO sometimes triggers a period of underperformance for the company, due to erroneous predictions about its future prospects (Gervais and Goldstein, 2007). Since they believe that there will be a possibility to repay the debt faster or get easy refinancing, overconfident managers more frequently decide on short-term financing, are less likely to pay dividends and are more eager to repurchase shares (Heaton, 2002). Finally, a recent study by Boulton and Campbell (2016) proved that managerial overconfidence positively relates to IPO underpricing. 


\section{LIMITATIONS}

This study is not free from limitations. First, although the response rate was relatively typical for other research in this area, the final study sample was not very large $(n=163)$. Second, our participants represented heterogeneous companies with respect to the studied numerical data, especially including the holding position in the company, its revenue and total assets or years being publicly listed. Finally, although the questionnaire was adopted from behavioural finance literature, and was thus used in other studies on investors and managers, it could still appear relatively artificial to corporate managers who cope with much more complex financial decisions in the company.

\section{CONCLUSIONS}

Despite these limitations, since the application of a behavioural paradigm to corporate finance remains an understudied research area, this study adds to the literature. Overall, it appears that even well-educated corporate managers with a high level of expertise and representing publicly listed companies, are susceptible to overconfidence bias, which may be related to their irrational managerial practices in the area of IPO decisions. Therefore, further research on behavioural corporate finance is needed to better understand the psychological obstacles that managers face in their everyday decisions regarding a company's value creation.

\section{REFERENCES}

Akerlof, G.,Schiller, R., How Human Psychology Drives the Economy and Why It Matters for Global Capitalism. Princeton University Press, Ewing, NJ, 2009.

Baddeley, M., Behavioral Economics and Finance. University Press, Cambridge 2013.

Baker, M., Nofsinger, J., Behavioral Finance, Investors, Corporation and Markets (vol. 2). J. Wiley \& Sons, Hoboken, NJ, 2010.

Baker, M., Wurgler, J, A Catering Theory of Dividends, "Journal of Finance”, 59, pp. 11251165, 2004.

Baker, M., Wurgler, J., Behavioral corporate finance: An Updated Survey [in:] Constantinides, G., Harris, M., Stulz, R. (eds.). Handbook of the Economics and Finance. Elsevier, Amsterdam 2013.

Ben-David, I., Graham, J., Harvey, C., Managerial Overconfidence and Corporate Policies. NBER Working Paper No. 13711, https://www.nber.org/papers/w13711, 2007. 
Boulton, T., Campbell, T. Managerial confidence and initial public offerings, "Journal of Corporate Finance", 37, pp. 375-392, 2016.

Brau, J., Fawcett, S. E., Initial public offerings: An analysis of theory and practice, "Journal of Finance", 61, pp. 399-436, 2006.

Brown, W., Crabb, P., Haushalter, D., Are Firms Successful at Selective Hedging?, "Journal of Business", 79, pp. 2925-2949, 2006.

Camerer, C., Loewenstein, G., Behavioral Economics: Past, Present, Future. Mimeo, Carnegie Mellon University, 2003.

Damodaran, A., Corporate Finance, Theory and Practice. Wiley, New York 2001.

De Bondt, W., Thaler, R., Further Evidence on Investor Overreaction and Stock Market Seasonality, "Journal of Finance", 3, pp. 557-580, 1987.

De Bondt, W., Thaler, R., Financial Decision-Making in Markets and Firms: A Behavioral Perspective. NBER Working Paper No. 4777, https://www.nber.org/papers/w4777, 1994.

De Bondt, W, Muradoglu, G., Shefrin, H., Staikouras, S., Behavioral Finance: Quo Vadis?, "Journal of Applied Finance", 18, pp. 7-21, 2008.

Gervais, S., Goldstein, I., The Positive Effects of Biased Self-Perceptions in Firms, "Review of Finance", 11, pp. 453-496, 2007.

Graham, J., Harvey, C., The Theory and Practice of Corporate Finance: Evidence from the Field, "Journal of Financial Economics", 60, pp.187-243, 2001.

Heaton, J., Managerial Optimism and Corporate Finance, "Financial Management Association", 31, pp. 33-45, 2002.

IBM Corp. Released, IBM SPSS Statistics for Windows. Version 24. Armonk, NY: IBM Corp, 2016.

Itzkowitz, J., Itzkowitz, J., Name-Based Behavioral Biases: Are Expert Investors Immune?, "Journal of Behavioral Finance", 18, pp. 180-188, 2017.

Kahneman, D., Tversky, A., Prospect Theory, an Analysis of Decisions under Risk. "Econometrica", 47, pp. 263-292, 1979.

Kahneman, D., Thinking fast and slow. Penguin Books Ltd, New York, NY, 2012.

Krems, J., Zierer, C., Are Experts Immune to Cognitive Bias? Dependence of "Confirmation Bias" on Specialist Knowledge, "Zeitschrift für Experimentelle und Angewandte Psychologie", 41, pp. 98-115, 1994.

Jain, B., Kini, O., The post-issue operating performance of IPO firms, "Journal of Finance", 49, pp. 1699-1726, 1994.

Langer, E., The Illusion of Control, "Journal of Personality and Social Psychology", 32, pp. 311-328, 1975.

Lerner, J., Venture capitalists and the decision to go public, "Journal of Financial Economics", 35, pp. 293-316, 1994.

Lichtenstein, S., Fischhoff, B., Do Those Who Know More Also Know More about How Much They Know?, "Organizational Behavior and Human Performance”, 20, pp. 159-183, 1977.

Lichtenstein, S., Fischoff, B., Philips, L., Calibration of Probabilities: The State of the Art to 1980 [in:] Kahneman, D., Slovic, P., Tversky, A. (eds.). Judgment Under Uncertainty: Heuristics and Biases, pp. 306-334. Cambridge University Press, Cambridge 1982. 
Ljungqvist, A., Wilhelm, W., Jr., Does Prospect Theory Explain IPO Market Behavior?, "Journal of Finance", 60, pp. 1759-1790, 2005.

Loughran, T., Ritter J., The New Issue Puzzle, “Journal of Finance”, 50, pp. 23-51, 1995.

Loughran, T., Ritter, J., Rydqvist, K., Initial public offerings: International insights, "PacificBasin Finance Journal”, 2, pp. 165-199, 1994.

Malmendier, U., Tate, G., CEO Overconfidence and Corporate Investment, "Journal of Finance", 60, pp. 2661-2700, 2005a.

Malmendier, U., Tate, G., Does Overconfidence Affect Corporate Investment? CEO Overconfidence Measures Revisited, "European Financial Management", 11, pp. 649-659, 2005 b.

Malmendier, U., Tate, G., Who Makes Acquisitions? CEO Overconfidence and the Market's Reaction, "Journal of Financial Economics", 89, pp. 20-43, 2008.

Malmendier, U. \& Tate, G, Behavioral CEOs: The Role of Managerial Overconfidence, "Journal of Economic Perspectives", 29, pp. 37-60, 2015.

Malmendier, U., Tate, G., Yan, J., Overconfidence and Early-life Experiences: The Effect of Managerial Traits on Corporate Financial Polices, "Journal of Finance”, 66, pp. 16871733, 2011.

Mikkelson, W., Partch, M., Shah, K., Ownership and operating performance of companies that go public, "Journal of Financial Economics", 44, pp. 281-308, 1997.

Nguyen, T., Schussler, A., How to make better decisions? Lessons from behavioral corporate finance, "International Business Research", 6, pp. 187-198, 2013.

Niu, J., The Effect of Overconfidence on the Sensitivity of CEO Wealth to Equity Risk, "Journal of Financial Services Research", 38, pp. 23-39, 2010.

Pagano, M., Panetta, F., Zingales, L., Why do companies go public? An empirical analysis, "Journal of Finance", 53, pp. 27-64, 1998.

Ritter, J., The long-run performance of initial public offerings, "Journal of Finance", 46, pp. 3-27, 1991.

Rzeszutek, M., Szyszka, A., Czerwonka, M., Investor's expertise, personality traits and susceptibility to behavioral biases in the decision making process, "Contemporary Economics", 9, pp. 337-352, 2015.

Shefrin, H., Statman, M., The Disposition to Sell Winners too Early and Ride Losers too Long: Theory and Evidence, "Journal of Finance", 11, pp. 777-791, 1985.

Shiller, R., From Efficient Markets Theory to Behavioural Finance, "Journal of Economic Perspectives", 17, pp. 83-104, 2003.

Stephan, E. Kiell, G., Decision Processes in Professional Investors: Does Expertise Moderate Judgment Biases? [in:] Hoezl, E. (ed.). Fairness and Competition. Proceedings of the IAREP/SABE Conference, pp. 1-6. WUV, Vienna, Austria, 2006.

Szyszka, A., Generalized Behavioral Asset Pricing Model. SSRN Working paper http://dx.doi.org/ 10.2139/ssrn.1298910, 2008.

Szyszka, A., Preferences and Belief Based Models [in:] Baker, K., Nofsinger, J. (eds.). Behavioral Finance: Investors, Corporations, and Markets, pp. 351-372. J. Wiley \& Sons, Hoboken, NJ, 2010. 
Szyszka, A., Behavioral Finance and Capital Markets. How Psychology Influences Investors and Corporations. Palgrave Macmillan, New York 2013.

Thaler, R., Advances in Behavioral Finance. Princeton University Press, 2005.

Thaler, R., Misbehaving: The Making of Behavioral Economics. Princeton University Press, 2015.

van der Sar, N., Behavioral finance: How matters stand, "Journal of Economic Psychology", 25, pp. 425-444, 2004.

Weinstein, N., Unrealistic Optimism About Future Life Events, "Journal of Personality and Social Psychology", 39, pp. 806-820, 1980.

Welch, I. Corporate finance. An Introduction. Prentice Hall, New York 2009.

Received: March 2019, revised: September 2019

Acknowledgments: The authors wish to acknowledge financial support for conducting this study from the National Science Centre, Poland, under the grant No. 2016/23/B/HS4/ 01283. 


\section{APPENDIX}

\begin{tabular}{|c|c|c|c|c|}
\hline \multicolumn{5}{|c|}{ NUMERICAL INFORMATION ABOUT THE COMPANY } \\
\hline & \multicolumn{4}{|c|}{ The number of the Company's Management Board } \\
\hline 1 & \multicolumn{3}{|l|}{ Single person } & \\
\hline 2 & \multicolumn{3}{|c|}{ Multi-person, but financial decisions are made by CFO } & \\
\hline 3 & \multicolumn{3}{|c|}{ Multi-person in which financial decisions are taken collegially } & \\
\hline & \multicolumn{4}{|c|}{ Held position } \\
\hline 1 & \multicolumn{3}{|l|}{ CEO } & \\
\hline 2 & \multicolumn{3}{|l|}{ CFO, member of the Board } & \\
\hline 3 & \multicolumn{3}{|c|}{ CFO, but not a member of the Board } & \\
\hline & \multicolumn{4}{|c|}{ Other top managerial positions } \\
\hline 1 & \multicolumn{3}{|c|}{$\begin{array}{l}\text { The net revenues of the Company in the last reporting year are in the range } \\
\text { of }\end{array}$} & \\
\hline 2 & \multicolumn{3}{|c|}{ Below PLN 100 million } & \\
\hline 3 & \multicolumn{3}{|l|}{ PLN 100-500 million } & \\
\hline 4 & \multicolumn{3}{|l|}{ PLN 500 million-1 billion } & \\
\hline \multirow[t]{2}{*}{5} & \multicolumn{3}{|l|}{ PLN Over 1 billion } & \\
\hline & \multicolumn{4}{|c|}{ The total assets of the Company as at the end of the last reporting year were } \\
\hline 1 & \multicolumn{4}{|c|}{ Below PLN 100 million } \\
\hline 2 & \multicolumn{3}{|l|}{ PLN 100-500 million } & \\
\hline 3 & \multicolumn{3}{|l|}{ PLN 500 million-1 billion } & \\
\hline 4 & \multicolumn{3}{|l|}{ PLN Over 1 billion } & \\
\hline & \multicolumn{4}{|c|}{$\begin{array}{l}\text { M5. The share of debt in enterprise financing, i.e. interest liabilities to the balance } \\
\text { sheet total as at the end of the last reporting year, was about: ................\% }\end{array}$} \\
\hline & \multicolumn{4}{|c|}{$\begin{array}{l}\text { M6. The company operates in the sector: Instruction: Please select only one, } \\
\text { leading sector }\end{array}$} \\
\hline 1 & construction & 2 & chemical & \\
\hline 3 & light industry & 4 & heavy industry & \\
\hline 5 & mining industry & 6 & trade & \\
\hline 7 & biotechnology and pharmacy & 8 & IT & \\
\hline \multirow[t]{2}{*}{9} & \multicolumn{4}{|l|}{ other.............. } \\
\hline & \multicolumn{4}{|c|}{ M7. State Treasury hold over $15 \%$ of the Company's shares } \\
\hline \multirow[t]{2}{*}{1} & Yes & 2 & No & \\
\hline & \multicolumn{4}{|c|}{$\begin{array}{l}\text { M8. The company's shares are listed on the instruction: Please select only one } \\
\text { answer }\end{array}$} \\
\hline 1 & GPW & 2 & NewConnect & \\
\hline & \multicolumn{4}{|c|}{ M7. For how long the company's shares have been publicly traded (months) } \\
\hline
\end{tabular}

Source: authors' own. 


\section{PART I - BEHAVIORAL BIASES}

Please answer each of the following questions according to your best knowledge, belief or intuition.

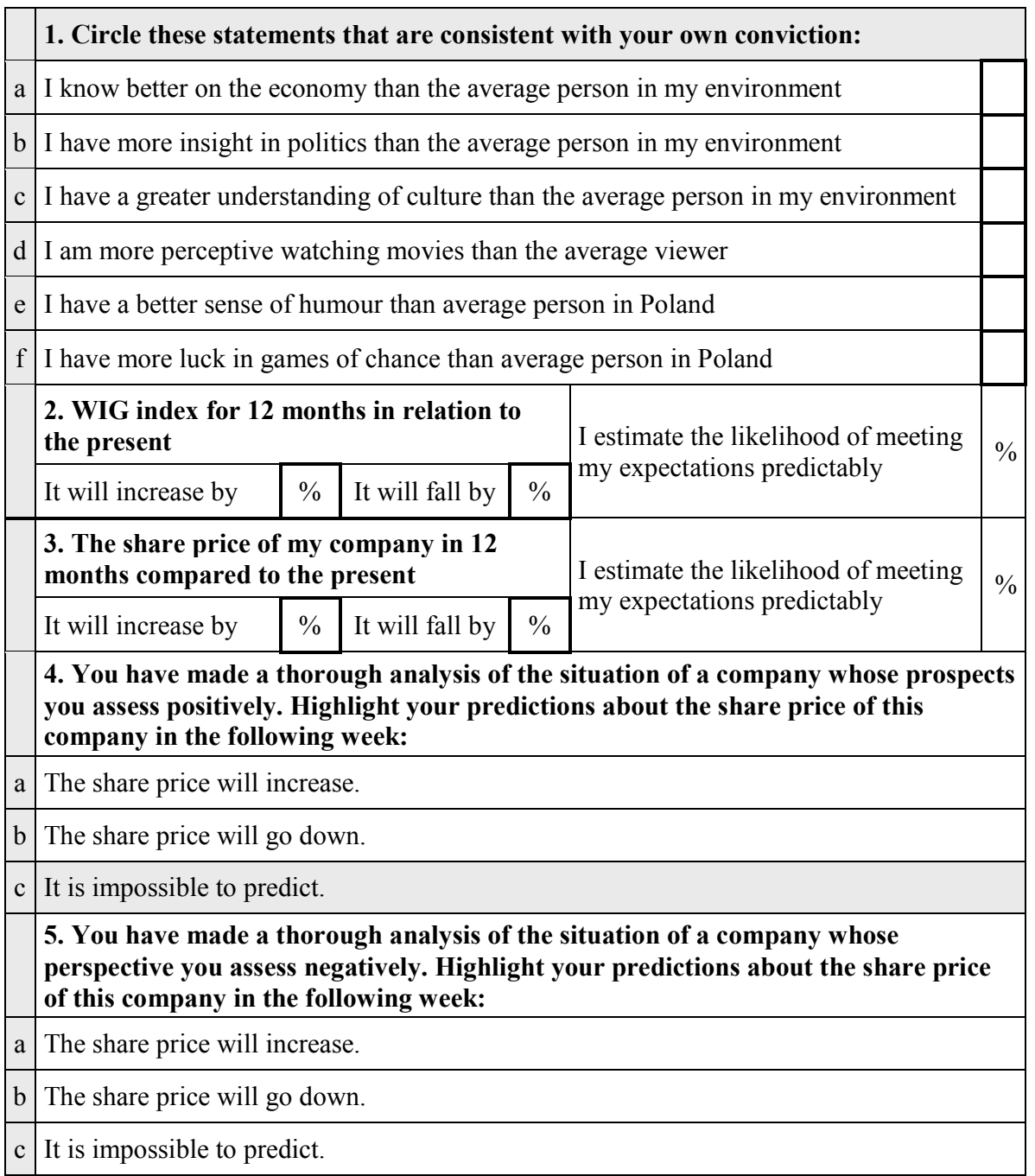




\section{PART II -MANAGERIAL PRACTICES}

\begin{tabular}{|c|c|c|}
\hline & \multicolumn{2}{|l|}{$\begin{array}{l}\text { 1. The decision on the public issue of shares and entry on the WSE was dictated by } \\
\text { (one answer): }\end{array}$} \\
\hline $\mathrm{a}$ & capital needs of the company & \\
\hline $\mathrm{b}$ & the need to liquidate some or all of the shares by existing shareholders & \\
\hline $\mathrm{c}$ & booming stock market and possible valuation of shares & \\
\hline $\mathrm{d}$ & the desire to capitalize on the company's good historical results & \\
\hline \multirow[t]{2}{*}{$\mathrm{e}$} & the desire to strengthen the company marketing position & \\
\hline & 2. In your opinion, the shares of the company are currently: & \\
\hline a & properly valued by the market & \\
\hline \multirow[t]{2}{*}{$\mathrm{b}$} & undervalued & \\
\hline & \multicolumn{2}{|l|}{$\begin{array}{l}\text { 3. When introducing the company to the stock exchange during the period of a } \\
\text { long-term boom: }\end{array}$} \\
\hline $\mathrm{a}$ & $\begin{array}{l}\text { I am striving to make my debut as fast as possible so that the prosperity is not } \\
\text { over. }\end{array}$ & \\
\hline \multirow[t]{2}{*}{$\mathrm{b}$} & $\begin{array}{l}\text { I delay the date of the debut in order to achieve the highest possible price for } \\
\text { shares in the public offer. }\end{array}$ & \\
\hline & \multicolumn{2}{|l|}{$\begin{array}{l}\text { 4. By introducing the company to the stock exchange during the long-term bear } \\
\text { market: }\end{array}$} \\
\hline a & $\begin{array}{l}\text { I am striving to make my debut as fast as possible so that the economic situation } \\
\text { will not deteriorate even more. }\end{array}$ & \\
\hline \multirow[t]{2}{*}{$\mathrm{b}$} & $\begin{array}{l}\text { I delay the date of the debut, hoping that the economic situation will be reversed } \\
\text { soon and we will be able to obtain a higher price for shares in the public offer. }\end{array}$ & \\
\hline & \multicolumn{2}{|l|}{$\begin{array}{l}\text { 5. By introducing the company to the stock exchange during the period of long- } \\
\text { term boom: }\end{array}$} \\
\hline $\mathrm{a}$ & $\begin{array}{l}\text { I am willing to offer investors a higher discount in the public offering in relation } \\
\text { to the market valuation, as the current market valuation of the company is still } \\
\text { very high. }\end{array}$ & \\
\hline \multirow[t]{2}{*}{$\mathrm{b}$} & $\begin{array}{l}\text { I offer investors a lower discount in the public offer in relation to the market } \\
\text { valuation, because during the bull market shares will find buyers easily. }\end{array}$ & \\
\hline & $\begin{array}{l}\text { 6. By introducing the company to the stock exchange during the long-term } b \\
\text { market: }\end{array}$ & \\
\hline a & $\begin{array}{l}\text { I am willing to offer investors a lower discount in the public offer in relation to } \\
\text { the market valuation, as the current market valuation of the company is low } \\
\text { during the bear market. }\end{array}$ & \\
\hline $\mathrm{b}$ & $\begin{array}{l}\text { I am willing to offer investors a higher discount in the public offering in relation } \\
\text { to the market valuation, to make it easier to place shares in the bad economic } \\
\text { situation. }\end{array}$ & \\
\hline
\end{tabular}

These are all the questions. At the end, please select one of the following charity goals, which in your opinion is worth supporting (PLN 10 from each completed survey will be allocated to the target indicated by the largest number of respondents): 


\begin{tabular}{|c|c|}
\hline & Choose a charity goal \\
\hline 1 & $\begin{array}{l}\text { "Action Parcel" organized by Fundacja Niesiemy Nadzieję and Stowarzyszenie } \\
\text { Wielkopolanie Bona Fide - Christmas parcels for poor families and sick children }\end{array}$ \\
\hline 2 & Caritas - for clothing and food for the poor \\
\hline 3 & $\begin{array}{l}\text { Rotary Club - intended to support a student or young scientist leaving for } \\
\text { internships }\end{array}$ \\
\hline 4 & $\begin{array}{l}\text { Wielkopolskie Towarzystwo Edukacyjno-Kulturalne - intended for supporting a } \\
\text { poor student in paying tuition for a dormitory }\end{array}$ \\
\hline 5 & $\begin{array}{l}\text { Siepomaga Foundation - for the development of the first online charity platform } \\
\text { in Poland }\end{array}$ \\
\hline
\end{tabular}

